\title{
Philosophy education: "tut wuri handayani" as the spirit of process governance in Indonesia educational organization
}

\author{
Agus Hermawan ${ }^{\left.1^{*}\right)}$, Emily B. Tan ${ }^{2}$ \\ ${ }^{1}$ University of Santo Tomas, Graduate School, Manila, Philippines \\ ${ }^{2}$ Santo Domingo Convent, 537 Quezon Avenue, St. Peter, Quezon City 1114, Philippines
}

\section{Article Info \\ Article history: \\ Received June $28^{\text {th }}, 2021$ \\ Revised Oct $13^{\text {th }}, 2021$ \\ Accepted Nov 03 ${ }^{\text {rd }}, 2021$ \\ Keyword: \\ Organization governance Process governance model Philosophy of education Tut wuri handayani

\begin{abstract}
'Tut wuri handayani' is the slogan of the National Education of Indonesia, written in Sanskrit. It is a Philosophy of Education which was originally promoted by Ki Hajar Dewantara. Practically, it is an accumulation of educational processes that prioritize the transformation of good character and knowledge through Organization Governance that is instigated by educational leadership. In this regard, the paper utilizes literature review method to get information from researchers published in refereed journals regarding process governance, model of organization governance in school and synthesizes the information to show how "Tut Wuri Handayani" can be promoted by the school leaders in order that it can be integrated in the school governance. This paper invites researchers to apply qualitative research designs to explore the possibility of the implementation the Philosophy Education: "Tut Wuri Handayani" in Organization Governance of Schools in Indonesia.
\end{abstract}

(C) 2021 The Authors. Published by IICET

This is an open access article under the CC BY-NC-SA license

(https://creativecommons.org/licenses/by-nc-sa/4.0

\section{Corresponding Author:}

Agus Hermawan

University of Santo Tomas

Email: agus.hermawan.gs@ust.edu.ph

\section{Introduction}

Education is a process to develop the human potentials in all aspects such as intellectual, social, cultural, political, and technological and the ways of thinking until these potentials become real acts and effective for human life. It includes how to address educational problems through a philosophical approach so that the solutions to the problems can also be understood by all concerned parties. For this reason, most of the educational organizations, especially public schools in Indonesia adapt the value of the Philosophy of Education: 'Tut Wuri Handayani'. 'Tut Wuri Handayani' is a short form of the slogan 'Ing Ngarso Sing Tulodo, Ing Madya Mangun Karso, and Tut Wuri Handayani', which was introduced by Ki Hajar Dewantara in 1922. It was derived from the local wisdom and situation in Indonesia during that time. Ki Hajar Dewantara was the first Ministry of Education, Republic of Indonesia. He was the Father of National Education who transformed educational system from colonialism to nationalism approach (Nisa, et al., 2019).

Literarily, 'Ing Ngarso Sing Tulodo' means "in front should set a good example". It could be applied by the school leaders and educators to give good examples for the students. A teacher should be a role model in order to show the students how to behave in daily life, apply the values in life, and act accordingly as a learner (Koesoema, 2017). In addition, 'Ing Ngarsa Sing Tulodo' emphasizes on the ability of a teacher to be a role model so that students can listen to the teacher's advice and imitate the teacher (Dwikurnaningsih, 2017). 'Ing Madya Mangun Karso' literarily means "in the middle should take the initiative and create a goal". The teacher 
as an educator should continuously develop students' enthusiasm and ideas to create something new (Dwikurnaningsih, 2017). 'Ing Madya Mangun Karso' should be implemented in teaching so that the teacher shall be in the middle of the students encouraging their will to be independent people. Students who are enthusiastic and creative are a result of education, which help students develop good traits. Therefore, the teachers should contribute their skills and talents for the country's education by helping the students build their potentials to help themselves, the nation, and others (Darmawan, 2019).

Lastly, 'Tut Wuri Handayani' literarily means "at the back should give support". This slogan wants to emphasize the role of educator as a motivator and supporter for their students to achieve their best potentials. This understanding could also be applied by the school leaders and educators who should give good examples for their students (Darmawan, 2019). It is necessary for the teachers to give encouragement and guidance to their students from behind (Samuel et al., 2017), so that the students can learn how to be more responsible in every decision they make. 'Tut Wuri Handayani' emphasizes that education should balance a student's intelligence with his/her personality (Supriyoko, 2017).

In summary, 'Ing Ngarso Sing Tulodo, Ing Madya Mangun Karso, and Tut Wuri Handayani' is a dynamic principle and practice within an educational organization. It is connected not only to teaching method but also to leadership and other educational processes which involve teachers and students in the teaching learning process through an integral way (Karyawanto \& Ms, 2018). This paper shows the readers the necessity and benefits of Philosophy Education: 'Tut Wuri Handayani' in Organization Governance of Schools in Indonesia, especially in applying the Process Governance Model.

\section{Governance in Educational Organization}

We usually link Organization Governance to a system of an organization that prevents negative things like corruption, scandal, or protects organization from natural disasters or other unexpected incidents. However, a successful implementation of Organization Governance refers to a systematic approach which includes strategic planning, risk management and well-organized management performance. The word governance can be described as a system that regulates the structure, character, accountability, and decision-making process by the top management in an organization. Governance aims to set and accomplish organizational goals and monitor and minimize risk by optimizing performance (Governance Today, 2021). This shows that Organization Governance is both a system and a process. It requires an effective and systematic methodology that integrates planning and management process to successfully achieve the organization's goals. It is not a single activity, but several activities of the management that protect the various stakeholders' interests. Governance is a core element of a successful organization.

Organization Governance in educational organization can be a system of restructuring the people and processes involved in the teaching and learning activities. This system or process works towards the efficient functioning of the school/university as a whole. Generally, school governance aims to prosper the teachinglearning experiences in an integral way. This includes selecting the competent teachers, the correct curriculum, practices, and philosophy which aligns with the school's goals and objectives. Then, the school stakeholders arrange the application of government intervention, direct the education specifications, and take over the structural responsibility in education (Saguin, 2019). Effective organization governance also fosters school culture and organization by maintaining a clear level of accountability and communication within the organization.

For example, teachers or educators are expected to address the concerns of parents regarding the academic progress, time management, lack of self-motivation and other problems regarding the study of their children. The school management has to help parents address these issues and in partnership with the teachers have the initiative to solve the problem/s and suggest ways to reduce or resolve the problem/s. To ensure proper implementation of organization governance, teachers must enrich their home-school collaboration efforts in order to facilitate an effective program with parents to help their children adjust to the curriculum. Effective governance requires school leaders and teachers to apply effective collaboration and communication for improvement of student performance and consequently, improvement of the organization.

\section{Process Governance as a Model of Organization Governance in School}

Process Governance Model directs process management within an organization to build a mutual relationship between intention and sustainable development. Organization elements such as: roles, responsibilities, standards, structure, and goals, as well as control and evaluation mechanisms are carefully coordinated through this model. Thus, the main aim of this model is to regularly facilitate the management process through its elements and improve the governance performance (Kirchmer, 2017). Process Governance Model in schools ensures proper leadership and instructional delivery during the education process. Teachers must be 
immersed in varied professional development courses, learning innovative teaching techniques in actual or virtual classroom, and assessment of the implementation of curriculum and instruction.

Process Governance is very important in the educational organization because it strengthens stakeholders' decision, supports education process, and provides the foundation for school achievements. It involves processes by which a school is directed, controlled, and held accountable. In order to maintain a good Process Governance, an organization needs qualified human resources, good leadership, clear direction and strong commitment from the stakeholders. If the strong commitment and proper Process Governance are practiced throughout the educational organization, success in education can be achieved (Kirchmer, 2017).

\section{"Tut Wuri Handayani" as the Spirit of Process Governance}

Based on the Ki Hadjar Dewantara's Philosophy of Education: 'Ing Ngarso Sung Tulodo' is the spirit that could inspire the school leaders and teachers to select the best practices and philosophy which are aligned with the school's mission and vision, then act accordingly. 'Ing Madya Mangun Karso' is the spirit that could direct the school leaders and teachers to be immersed in varied professional development courses in order to guarantee proper instruction delivery. 'Tut Wuri Handayani' is the spirit that could empower the school leaders and teachers to continuously observe and support the students' learning experiences through varied learning and assessment tools.

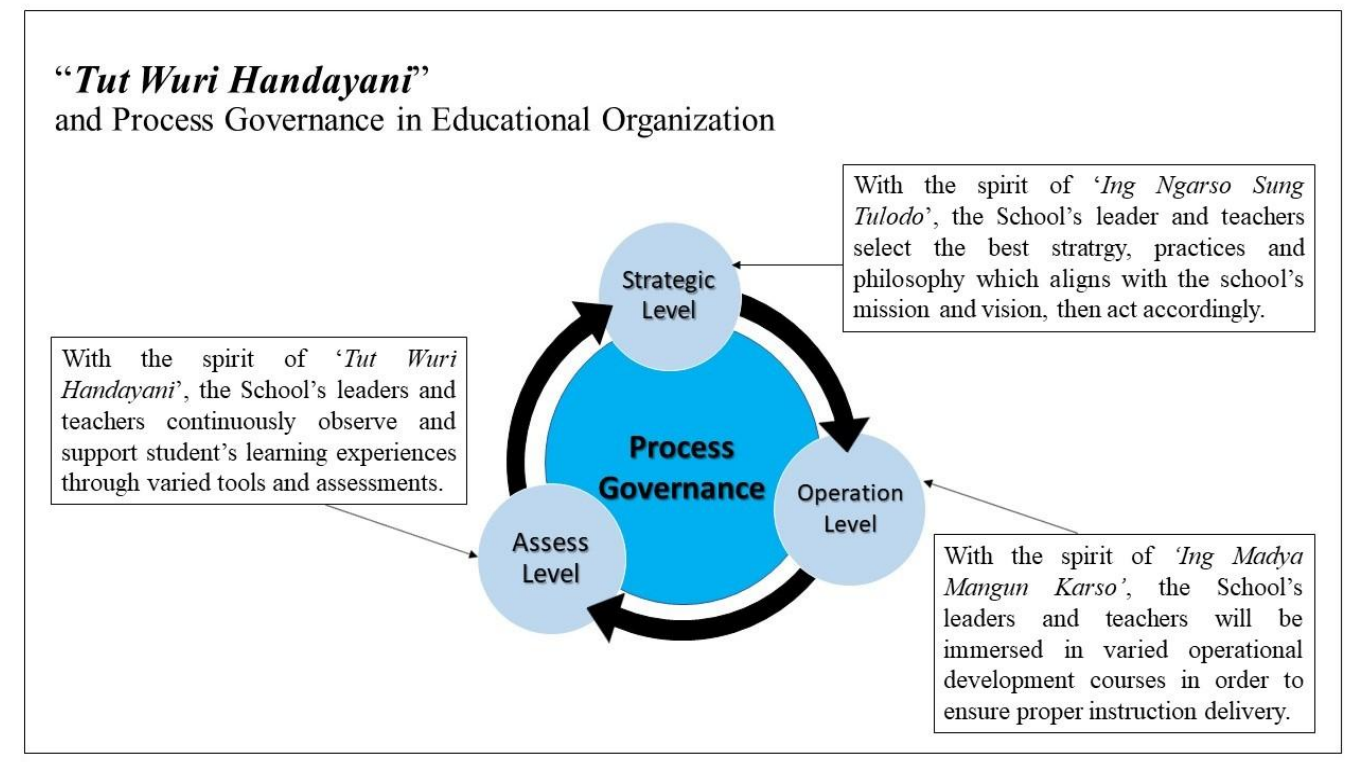

Figure 1. Tut Wuri Handayani' as the Spirit of Process Governance

\section{The Benefits of 'Tut Wuri Handayani' for Educational Organization Governance}

A good education will not emphasize merely on the cognitive aspects, but also affective and psychomotor skills. It is the responsibility of the teachers to help their students develop those skills (Saptandari, et al., 2015). Education is a process of fostering students' intelligence and character. By applying 'Tut Wuri Handayani' in school, the leaders and teachers have to give good examples, foster freedom, and positive values such as cultural, religious, nationalism, humane, accountability and responsibility.

Education transmits knowledge and skills of teachers to learners and builds the characters of learners through formal and informal ways. This objective is very essential for a nation to nurture their identity because it can assist students who will not disregard their culture and spirit of nationalism (Towaf, 2017). According to Ki Hadjar Dewantara, student freedom or independence is advocated in democratic education and leadership. (Nugroho, 2017). That's why 'Tut Wuri Handayani' idea aligns with student-centered learning.

The benefits of 'Ing Ngarso Sing Tulodo, Ing Madya Mangun Karso, and Tut Wuri Handayani' for educational organization governance in Indonesia are closer relationship between students and teachers due to social hierarchy in Indonesian culture; teachers as role models of the learners either at school or outside the school; adaption of the culture and other practices as sources of learning, learners' social sensitivity; and more independent, and responsible and create dynamic learners (Claramita, 2016). Furthermore the information about it will explain on the table 1 to present the benefits. 
Table 1. Benefits of "Tut Wuri Handayani” for Educational Organization Governance

\begin{tabular}{lll}
\hline Philosophy Education & \multicolumn{1}{c}{ Leadership Perspective } & \multicolumn{1}{c}{ Educational Perspective } \\
\hline Ing Ngarso Sung Tulodo & $\begin{array}{l}\text { A leader is the role model for } \\
\text { his/her members. }\end{array}$ & $\begin{array}{l}\text { A teacher provides good examples to } \\
\text { be a role model for his/her learners. }\end{array}$ \\
$\begin{array}{l}\text { Ing Madyo Mangun } \\
\text { Karso }\end{array}$ & $\begin{array}{l}\text { A leader in the middle of his } \\
\text { service arouses the work spirit of } \\
\text { his/her members. }\end{array}$ & $\begin{array}{l}\text { A teacher provides innovations in the } \\
\text { classroom environment to create a } \\
\text { safe for learning. }\end{array}$ \\
Tut Wuri Handayani & $\begin{array}{l}\text { A leader who follows behind, gives } \\
\text { a good and inspiring influence for } \\
\text { his/her members. }\end{array}$ & $\begin{array}{l}\text { A teacher does not force learners to the } \\
\text { front, but let them find their own way, } \\
\text { and when they go wrong, the teacher } \\
\text { may correct them. }\end{array}$ \\
\hline
\end{tabular}

The Roles of School Stakeholders in Fostering " Tut Wuri Handayani"

School stakeholders as leaders have a direct link to the school vision-mission and are the builders of the spirit of Process Governance in educational organization. The Philosophy of Education: 'Tut Wuri Handayani' had emphasized that teachers should follow the students who should lead their own learning process. We used to have a perception that a teacher should be present as a 'role model' of their students, who observe and follow him/her. However, a role model creates a free and independent person who can stand on his/her own feet based on what he has learned from the role model (Supriyoko, 2017). The role model may create the students' desire to do good things as the students have been exposed to good things done by their teacher. If students are exposed to good attitudes and behaviors of the models, the students will develop the same good values which would affect their lives (Darmawan, 2019).

On the one hand, the school stakeholders should establish clear school vision and mission to help principals, school leaders, and teachers enhance students' performance. They should do their tasks based on these, so that leadership in the organization will have significant influence on the students' academic performance and behavior. They should always be aware of their contribution to the development of the organizational culture in their school. They have the task to foster the value of 'Tut Wuri Handayani' in their school. It is necessary, so that this slogan of the National Education in Indonesia can guide students to the right path and help them become good citizens of Indonesia. On the other hand, in fostering 'Tut Wuri Handayani', the stakeholders need to articulate this Philosophy of Education in the vision and mission of the school. They must encourage school leaders and teachers to observe 'Tut Wuri Handayani' by communicating the vision and mission clearly through creative and friendly ways (Nisa, et al., 2019).

\section{Conclusions}

The educational system in Indonesia have undertaken different types of leadership. The study presents the importance and ways to promote this Indonesia Philosophy of Education; 'Tut Wuri Handayani' in order to conserve its value as a guide for good spirit and right conduct of all school leaders and teachers to attain the educational goals. School leaders and teachers are enjoined to apply this Indonesian Philosophy of Education to ensure good education of students anywhere and at any time. The authors also suggest the collaborative efforts of the module and curriculum developers, and the facilitators of learning to include the Philosophy of Education: 'Tut Wuri Handayani' as one of the principles and values in school governance. Moreover, this study proposes the future researchers to apply qualitative research designs to explore the impact of the implementation of 'Tut Wuri Handayani' on the learners, school leaders, teachers and other stakeholders in selected Indonesian schools.

\section{References}

Claramita, M. (2016). Revealing “Tut Wuri Handayani” - A Student-Centred Learning Approach - By Ki Hajar Dewantara From the Early 20th Century: A Literature Review. Jurnal Pendidikan Kedokteran Indonesia. University of Gajah Mada. Yogyakarta.

Darmawan, I.P.A., \& Sujoko, E. (2019). Understanding Ki Hadjar Dewantara's Educational Philosophy. International Journal of Humanities and Innovation (IJHI). https://doi.org/10.33750/ijhi.v2i3.42. 
Dwikurnaningsih, Y. (2017). Implementasi Pemikiran Ki Hadjar Dewantara dalam Kepemimpinan Pendidikan. Prosiding Seminar Nasional Dan Bedah Buku "Implementasi Dan Filosofi Ajaran Ki Hadjar Dewantara Dalam Dunia Pendidikan Masa Kini" Dan "Seminar Hasil-Hasil Penelitian Pendidikan." Presented at the Seminar Nasional dan Bedah Buku "Implementasi dan Filosofi Ajaran Ki Hadjar Dewantara dalam Dunia Pendidikan Masa Kini," Salatiga, Indonesia.

Governance Today (2021). Retrieved on May 1, 2021 from https://www.governancetoday.com/ GT/Material/Governance what is it and why is it important aspx

Karyawanto, H. Y., \& Ms, N. (2018). Sariswara Method as the Basis of Art Lesson in Tamansiswa. Presented at the 2nd Social Sciences, Humanities and Education Conference: Establishing Identities through Language, Culture, and Education (SOSHEC). https://doi.org/10.2991/soshec-18.2018.36

Kirchmer, M. (2017). Business Process Governance. High Performance Through Business Process Management. https://doi.org/10.1007/978-3-319-51259-4_5

Koesoema, D. (2017). Mempraktikkan Filosofi Ki Hadjar Dewantara. Prosiding Seminar Nasional Dan Bedah Buku "Implementasi Dan Filosofi Ajaran Ki Hadjar Dewantara Dalam Dunia Pendidikan Masa Kini" Dan "Seminar Hasil-Hasil Penelitian Pendidikan." Presented at the Seminar Nasional dan Bedah Buku "Implementasi dan Filosofi Ajaran Ki Hadjar Dewantara dalam Dunia Pendidikan Masa Kini," Salatiga, Indonesia.

Nisa, A.F., Prasetyo, Z.K., \& Istiningsih. (2019). The Teachings of Ki Hadjar Dewantara in Improving the Character of Elementary School Students in the Revolution of Industry 4.0. Advances in Social Science, Education and Humanities Research, International Conference on Educational Research and Innovation (ICERI).

Nugroho, L. (2017). The Implementation of an Trilogi Educational Leadership to Ki Hadjar Dewantara in Elementary School (SD) Taman Muda Ibu Pawiyatan Taman Siswa of Yogyakarta, Jurnal Kebijak. Pendidik., Yogyakarta, Indonesia.

Saguin, K.I. (2019). Designing effective governance of education, Policy Design and Practice. https://doi.org/10.1080/25741292.2019.1621034

Samuel, D., Miranda, G., \& Luhsasi, D. I. (2017). Pengembangan Model Evaluasi Metode Pembelajaran dalam Perspektif Kepemimpinan Guru. Presented at the Seminar Nasional dan Bedah Buku "Implementasi dan Filosofi Ajaran Ki Hadjar Dewantara dalam Dunia Pendidikan Masa Kini," Salatiga, Indonesia.

Saptandari, E. W., Harvey, S. T., Sewell, A., \& Bimler, D. T. (2015). The Importance of Researching Teachers'Social Emotional Competencies in an Indonesian Context. Proceeding of 1st Unnes International Conference on Research Innovation \& Commercialization for the Better Life 2015, 455. Semarang, Indonesia.

Supriyoko, K. (2017). Mengkaji Filosofi Pemikiran Ki Hadjar Dewantara. Prosiding Seminar Nasional Dan Bedah Buku "Implementasi Dan Filosofi Ajaran Ki Hadjar Dewantara Dalam Dunia Pendidikan Masa Kini" Dan "Seminar Hasil-Hasil Penelitian Pendidikan." Presented at the Seminar Nasional dan Bedah Buku "Implementasi dan Filosofi Ajaran Ki Hadjar Dewantara dalam Dunia Pendidikan Masa Kini," Salatiga, Indonesia.

Towaf, S.M. (2017). The National Heritage of Ki Hadjar Dewantara in Taman Siswa about Culture-Based Education and Learning," The 4th International Conference on Language, Society and Culture in Asian Contexts, $\mathrm{KnE}$ Social Sciences, Universitas Negeri Malang, Indonesia. https://doi.org/10.18502/kss.v1i3.768. 